\title{
Assessment Knowledge of the patients' with acute renal failure concerning dietary pattern in dialysis unite of AL-Zahraa Teaching Hospital at AL-Kut city
}

\author{
Faisal Younus Sameen ${ }^{1}$, Qassim Jawell Odah Abed ${ }^{2}$, Tareq Al-Qassab ${ }^{3}$, Ashwaq Yas Khudhair ${ }^{4}$ \\ ${ }^{1}$ M.Sc. Adult Nursing, University of Kirkuk-College of Nursing, ${ }^{2}$ M.Sc. Adult Nursing, AL-Kut Technical Institute- \\ Middle Technical University, ${ }^{3} \mathrm{PhD}$. Food Hygiene, AL-Kut Technical Institute-Middle Technical University-Iraq, \\ ${ }^{4}$ M.Sc. Biochemistry, Al-Karama Teaching Hospital, Lab. Biochemical-Ministry of Heath
}

\begin{abstract}
Objectives: To assess the knowledge of patients with acute renal failure concerning dietary pattern for kidney failure in dialysis unite in AL-Zahraa Teaching Hospital at AL-Kut City and Find out relationship between demographic data and knowledge of patient with acute kidney failure. By a non- probability sample account of (30) subjects is selected for the purpose of the present study. A questionnaire as aincomes for data gathering, it consist of two parts; include demographic data and knowledge of patients with acute renal failure concerning dietary pattern which composed of (18) items. By self-administration, data are collected from those who patients with renal failure come in dialysis unite in AL-Zahraa Teaching Hospital and analyzed through the used descriptive and inferential statistic approach. The study results indicated that the most of the participants are within married $(60 \%)$, and most of them are male. In regarding level of education, they most of them formally graduation, and administrative patients, as well the subjects have chronic disease such as diabetes mellitus and find statistical high significant between level of education and knowledge of patient at $p$-value $<0.05$ with non-significant between other demographical data
\end{abstract}

Keywords: Assessment, renal failure, dietary pattern.

\section{Introduction}

Acute kidney failure (AKF) is a disorder in which of therenal are incapable to eliminate waste the crops of breakdown. The disappointment of kidney purpose is quick in its start but possibly reversible. It happens speedily, within 8 wks of kidney damage subsequent in a fastrise in serum urea and creatinine courtesies in patients with beforehand standard kidney purpose ${ }^{(\mathbf{1})}$.It is a disorder usually associated with a high humanity rate, often due to the glitches of sepsis, latecoiled healing and troubledhaemocoagulation. Survivability has been recognized to be better by early suitable nutritional support ${ }^{(2)}$. Although in repetition this is

\section{Corresponding Author:}

\section{Faisal Younus Sameen}

M.Sc. Adult Nursing, University of Kirkuk-College of Nursing often problematic to achieve as nutritional support is multifaceted. In the past high disease and humanity rates were connected to infections and inadequate dietary intake. This resulted from unnecessary protein restrictions in an attempt to control uremicindications ${ }^{(3)}$. To a large degree survivability of acute renal failure has still not been prominently improved even with contemporary antibiotics and the careful nourishing valuation of acute renal disappointment patients. This reflects the difficulty of managing patients with this disorder. Though, appropriate nutritional management of ARF patients is essential to recover their long-term forecast $^{(\mathbf{4})}$. Although the precise form this takes remains a contentious issue between clinicians. The nourishment of kidney patients varies and their effect on the progress of the patient's disorder according to the stage in which the illness has been industrialized, we find that nutrition has a protective role and mitigation of the following symptoms if the kidney failure in the early stage. ${ }^{(5)}$ Should decrease the quantity of protein, as Urea is the 
creation produced by the breakdown of proteins in the body and upsurge the volume of protein in the body leads to increased effect on the kidneys, and consequently it is recommended to decrease the amount of protein in the diet rendering to the patient's condition.

\section{Methodology}

Study Objectives: To assess the knowledge of patients' with acute renal failure concerning dietary pattern for kidney failure in dialysis unite in AL-Zahraa Teaching Hospital at AL-Kut City

Find out relationship between demographic data and knowledge of patient with acute renal failure about dietary pattern

Study design :A descriptive study, using assessment method, is carried out to assess the knowledge of patients' with acute renal failure concerning dietary pattern for kidney failure in dialysis unite for AL-Zahraa Teaching Hospital at AL-Kut City. A non-probability simple random account of (30) patients who comes for dialysis. A questionnaire as resources of data collection was constructed for the purpose of study. It consisted from two parts, include:

Part I: This part contains demographical data which include (gender, address, marital status, level of education, chronic disease, and period of diagnosis).

Part II:this part about knowledge of patients with ARF concerning dietary pattern which composed from (18) items and answered on the question by Yes, or No, take time for each one (10-15) minute

Data analysis: Complete the used descriptive statistical (SPSS) form(21) analysis tactic that includes, frequencies, percentages, cruel of scores, standard divagation and graphical presentation of data; and inferential statistical data analysis approach that comprise ANOVA test.

\section{Result and Discussion}

Results signify the distribution of the patients' demographic items in term of frequencies and percentage. The Table (1) statistical analysis find patient with renal failure specific acute kidney failure have low level of knowledge concerning dietary pattern except questions $(4,5,6,7,11.15,16,17)$ due to mean score for this results in high level (1.812) these result agree with ${ }^{(6)}$ them study knowledge on dietary group among long-lasting renal disappointment patients experiencing hemodialysis at selected hospital, Kanchipuram. And find patient with chronic renal failure have knowledge deficiency concerning dietary management for renal failure and disagree with (7) he which studythat Assessment of the effectiveness of structured teaching package on knowledge regarding nutritionalorganization and casing care in renal failure among patients experiencing hemodialysis and find high level of knowledge for patients with chronic renal failure toward nutrition management. Regarding Table (3) this table shows that there is statistical significant association between patient' educational level and their knowledge concerning dietary pattern for renal failure $(\mathrm{p}$ value $<0.05$ ) when analyzed by ANOVA. There is No statistical significant association between nurses' (other demographic data) and their knowledge concerning dietary pattern for renal failure and agreement with ${ }^{(8)}$ A study to assess the knowledge and practice regarding dietary management of patients from rural area with end stage of renal disease undergoing hemodialysis in a selected hospital at Mysore. Find connection between patient knowledge and practice regarding nutrition management for end stage renal disease and level of education. Disagreement with ${ }^{(\mathbf{8})}$ he study is Aevocative study to assess the information on dietary running among chronic renal dissatisfaction patients undergoing hemodialysis, he find non-significant between knowledge of patients with chronic renal failure $(\mathbf{9 , 1 0 )}$.

Table (1): Distribution patient with acute renal failure knowledge concerning dietary pattern for kidney failure in dialysis unite

\begin{tabular}{|c|l|c|c|c|c|c|c|}
\hline $\mathbf{N}$ & \multirow{2}{*}{ Variables } & \multicolumn{2}{|c|}{ Yes answer } & \multicolumn{2}{|c|}{ No answer } & \multirow{2}{*}{ M.S } & Ass. \\
\cline { 2 - 5 } 1 & $\mathbf{f}$ & $\mathbf{\%}$ & $\mathbf{f}$ & $\mathbf{\%}$ & \\
\hline & $\begin{array}{l}\text { Did you know that renal insufficiency is a term used in the case of failure of } \\
\text { the kidneys to perform its functions }\end{array}$ & 13 & 44.0 & 17 & 56.0 & 1.57 & L \\
\hline 2 & $\begin{array}{l}\text { Did you know that urea is the toxins in the body that are thrown through the } \\
\text { kidneys }\end{array}$ & 12 & 40.0 & 18 & 60.0 & 1.60 & L \\
\hline
\end{tabular}




\begin{tabular}{|c|c|c|c|c|c|c|c|}
\hline \multirow{2}{*}{$\mathbf{N}$} & \multirow{2}{*}{ Variables } & \multicolumn{2}{|c|}{ Yes answer } & \multicolumn{2}{|c|}{ No answer } & \multirow{2}{*}{ M.S } & \multirow{2}{*}{ Ass. } \\
\hline & & f & $\%$ & f & $\%$ & & \\
\hline 3 & $\begin{array}{l}\text { Did you know that the main symptoms of acute kidney failure are lack of } \\
\text { urination, body buildup and high blood pressure }\end{array}$ & 10 & 24.0 & 20 & 66.0 & 1.67 & M \\
\hline 4 & $\begin{array}{l}\text { Did you know that dialysis is not a cure for renal failure, but is to reduce the } \\
\text { toxins in the body and the transplant is the ultimate treatment }\end{array}$ & 6 & 20.0 & 26 & 80.0 & 1.80 & M \\
\hline 5 & $\begin{array}{l}\text { Did you know that adherence to a healthy diet reduces the damage of } \\
\text { kidneys, especially patients with acute renal failure? }\end{array}$ & 5 & 16.0 & 25 & 84.0 & 1.83 & $\mathrm{H}$ \\
\hline 6 & $\begin{array}{l}\text { Did you know that the diet for patients with renal failure differs from the diet } \\
\text { of healthy people }\end{array}$ & 4 & 13.0 & 26 & 87.0 & 1.87 & $\mathrm{H}$ \\
\hline 7 & $\begin{array}{l}\text { Did you know that diet is an important part of the treatment plan and to } \\
\text { develop a diet suitable for the patient of renal failure in accordance with the } \\
\text { health status of the patient }\end{array}$ & 9 & 30.0 & 21 & 70.0 & 1.87 & $\mathrm{H}$ \\
\hline 8 & $\begin{array}{l}\text { Do you avoid foods that contain high water content such as soup, grapes, } \\
\text { watermelon, lettuce, tomatoes, celery }\end{array}$ & 13 & 44.0 & 17 & 56.0 & 1.57 & $\mathrm{~L}$ \\
\hline 9 & Do you avoid salty foods that increase your drinking water? & 6 & 20.0 & 24 & 80.0 & 1.80 & M \\
\hline 10 & $\begin{array}{l}\text { Do you avoid foods that contain vitamin A? Now it increases the calcium and } \\
\text { fat deposits in the body }\end{array}$ & 7 & 23.0 & 23 & 77.0 & 1.80 & M \\
\hline 11 & $\begin{array}{l}\text { An increase in salt intake causes fluid retention, so sodium should be reduced } \\
\text { in the diet because it helps control high blood pressure and prevents the body } \\
\text { from holding fluids. }\end{array}$ & 3 & 10.0 & 27 & 90.0 & 1.91 & $\mathrm{H}$ \\
\hline 12 & $\begin{array}{l}\text { Reduces phosphorus-containing foods such as milk, meat, poultry, nuts and } \\
\text { pulses because the increase in phosphorus leads to a lack of calcium in the } \\
\text { body, leading to a lack of bone building }\end{array}$ & 6 & 20.0 & 24 & 80.0 & 1.80 & M \\
\hline 13 & $\begin{array}{l}\text { Did you know eating large amounts of milk, vegetables and fish increases the } \\
\text { amount of calcium that your body needs to build muscle }\end{array}$ & 17 & 56.0 & 13 & 44.0 & 1.77 & M \\
\hline 14 & $\begin{array}{l}\text { Did you know that increasing the rate of potassium in the body is a danger } \\
\text { should avoid some foods such as potatoes, banana, apricot, orange, kiwi and } \\
\text { dried fruits such as raisins }\end{array}$ & 6 & 20.0 & 24 & 60.0 & 1.80 & M \\
\hline 15 & $\begin{array}{l}\text { You take the appropriate water of protein useful for the body was found in } \\
\text { white meat }\end{array}$ & 2 & 7.0 & 28 & 93.0 & 1.93 & $\mathrm{H}$ \\
\hline 16 & $\begin{array}{l}\text { Avoid foods that contain spices, especially canned foods, because they } \\
\text { contain sodium salts that build up fluids in the cells of the body }\end{array}$ & 5 & 16.0 & 25 & 84.0 & 18.3 & $\mathrm{H}$ \\
\hline 17 & $\begin{array}{l}\text { Avoid protein from nuts, seeds, peanut butter, dried peas, beans, and lentils } \\
\text { because they contain a high percentage of potassium and harmful calcium to } \\
\text { the body }\end{array}$ & 3 & 10.0 & 27 & 90.0 & 1.91 & $\mathrm{H}$ \\
\hline 18 & Exercise with adherence to diet reduces kidney damage & 4 & 13.0 & 26 & 87.0 & 1.87 & $\mathrm{H}$ \\
\hline
\end{tabular}

F: Frequency, P: Percentage, M.S: Mean of score, Asses = Assessment level, low $(1-1.60)=$ L, moderate $(1.61-1.80)=\mathrm{M}$, high $(1.81-2)=\mathrm{H}$

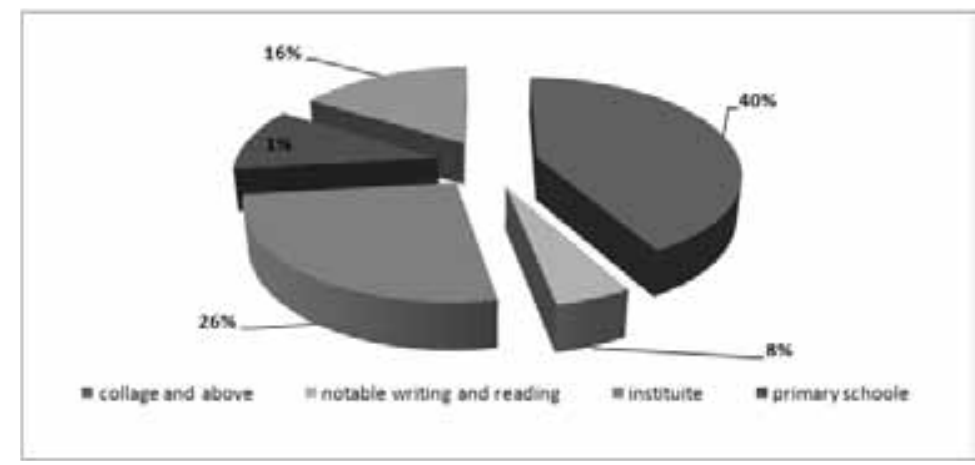

Figure (1) Show distribution between level of education for patient' with acute renal failure and knowledge about dietary pattern 
Table (2): Relationship between demographical data and knowledge of patient concerning dietary pattern

\begin{tabular}{|l|c|}
\hline Knowledge of patients & Level of education \\
\hline Notable read and write & $1.25+0.442$ \\
\hline Able to read and write & $1.31+0.471$ \\
\hline Primary school & $1.28+0.458$ \\
\hline Secondary school & $1.36+0.488$ \\
\hline Institute & $1.50+0.511$ \\
\hline Collage and above & $1.44+0.506$ \\
\hline
\end{tabular}

*F: $1.088 *$ d.f.: $2 *$ p. value : 0.346

\section{Conclusion}

The study concludes that more of the patients who come to dialysis unit in AL-Zahraa Teaching Hospital in AL-Kut City have low level of knowledge concerning dietary pattern that related to renal failure specific patients characterized by short period of diagnosis and low level of education

Recommendation: Study recommendation is established education program for teaching and increase patients knowledge concerning dietary pattern for renal failure and makes vide and poster with booklets which includes definitions the renal failure and nutrition management for kidney failure

Ethical Clearance: Permission from dialysis unite, in Al-Zahraa directorate was attained before starting the study. All the participants gave verbal consent with confidentiality of participants' identification

\section{Conflict of Interest: Nil}

\section{Source of Funding: Nil}

\section{References}

1. R. Manjunatha. A study to assess the knowledge and practice regarding dietary management of patients from rural area with end stage of renal disease undergoing hemodialysis in a selected hospital at Mysore. Cauvery college of nursing Mysore; 2017. Cited on: N0: 5- 6148-16.
2. Srinivasan K. A descriptive study to assess the knowledge on dietary management among chronic renal failure patients undergoing hemodialysis at selected hospital, Kanchipuram. Department of medical surgical nursing. Awadhmadhav college of nursing sciences and research, Gwallor: PID=20142-3-13

3. Pamidi S, Tasali E. Obstructive sleep apnea and type 2 diabetes: is there a link? Front Neurol. 2012;3:126. Available from: http://www.ncbi.nlm. nih.gov/pubmed/23015803

4. Kosseifi S, Bailey B, Price R, Roy TM, Byrd RP, Peiris AN. The association between obstructive sleep apnea syndrome and microvascular complications in well-controlled diabetic patients. Mil Med [Internet]. $2010,175(11): 913-6$. Available from: http://www.ncbi.nlm.nih.gov/pubmed/21121505

5. Blakeley, Sara (2010). Renal Failure and Replacement Therapies. Springer Science \& Business Media. p. 19. ISBN 9781846289378.

6. Bostrom, M.A.; Freedman, B.I. (2010). "The Spectrum of MYH9-Associated Nephropathy". Clinical Journal of the American Society of Nephrology. 5 (6): 1107-13. DOI:10.2215/ CJN.08721209. PMC.

7. Ricci, Zaccaria; Ronco, Claudio (2012). "New insights in acute kidney failure in the critically ill". Swiss Medical Weekly. 142: w13662

8. Fadem, Stephen Z., M.D., FACP, FASN. Calculators for Health Care Professionals. National Kidney Foundation. 2008. 13.

9. Charles RF, Powe NR, Jaar BG, Troll MU, Parekh RS, Boulware LE. Clinical testing patterns and cost implications of variation in the evaluation of CKD among US physicians. Am J Kidney Dis. 2009;54(2):227-237.

10. Whaley-Connell A, Sowers JR, McCullough PA, Roberts T, McFarlane SI, Chen SC, Li S, Wang C, Collins AJ, Bakris GL. KEEP Investigators: Diabetes mellitus and CKD awareness: the Kidney Early Evaluation Program (KEEP) and National Health and Nutrition Examination Survey (NHANES) Am J Kidney Dis. 2009; 53(4 Suppl 4):S11-S21. 